\title{
INTRODUCTION
}

\section{In medias res, A Moment of Silence}

\author{
Justin A. Joyce Emory University
}

Keywords: James Baldwin, 2016 U.S. presidential election, shuttle orbiter Challenger (OV-099), Hillary Clinton, Vladimir Putin, Pyongyang

I must have been in third grade when the U.S. space shuttle Challenger exploded just 73 seconds after launch in 1986. I don't remember the images we saw on the TV that day, but thirty years later I can recall the room we were in with crystalline clarity. Cramped in a cold classroom in Colorado, kids, teachers, and staff all juggled coats and jostled for position that January morning. We'd been pulled in early from recess in the cold, hustled hurriedly together so that we could watch the big launch together. The clammy feel of still-wet snowsuits and an overabundance of coats, the position of the rolling TV cart just inside the door, on the right side of the chalkboard. The whispers of excited children alternately swaying in a perpetual dance with the shushes of the adults. We'd all been prepped ahead of time and the whole school was rallying behind this "historic first" for the space program: a teacher was going to get to go to space! Our hearts and hopes soared with Christa McAuliffe and the other astronauts-but mostly for Christa, the teacher turned astronaut-for those first 72 seconds. And then I just remember quiet. The most sudden shut-off of all the sounds in the world, the deepest and most profound silence I'd yet heard in my life. The quiet of a room full of adults who suddenly have no idea what they're supposed to be telling the children in their charge.

A blip on the TV, a moment of smoke on the screen, and suddenly the world was forever changed. There were no words at hand for the adults in the room that day. I'm sure soothing platitudes were attempted, but on lifeless wings those vague reassurances fell so short that mostly nothing was said at all. The narrative was different now, and the language needed to adapt to this new narrative lagged behind. Hands were held, tears wiped, and hugs exchanged, but no one had words ready just yet. The whole rest of the day was blanketed in a silence as bracing as the cold outside.

There have certainly been other earth-shattering events I've witnessed from afar, but this one stands out as the first moment I personally witnessed a

James Baldwin Review, Volume 3, 2017 ( ) The Authors. Published by Manchester University Press and The University of Manchester Library 
collective loss of faith, watched it disappear all in a moment as if someone had flipped a diabolical switch. When all sound rushed out of the room, it ushered our hope out with it. As a child I saw-for the first time-adults and figures of authority utterly without compass or guide. McAuliffe's ascent to the cockpit of a space shuttle had epitomized our meritocratic values writ large-she had bested more than 10,000 other teachers in a national competition and she was now going to get to be an astronaut! Her peers and colleagues wept that day, openly, which was also quite an event for a third grader to witness. Yet in my memory they are crying in silence, their anguished faces contorted like Edvard Munch's screamer, devoid not only of sound, but also of meaning. The vacuum created when the words no longer fit, the silence of disbelief when, right in the middle of things, the whole story changes. That sort of silence is momentous precisely because it is so rare. But I've heard it again recently, and am now listening for it each day.

Since that day in third grade, the meaning of those silences has shifted a bit, but never so profoundly as when I became a parent. You see, I've two charges of my own now, twins, who just began primary schooling this year. Vocational vagaries, history, and habitus have landed us in a towny suburb in southeastern Michigan, just outside Detroit. We are exactly adjoining a crumbling urban center barely climbing out of a historic bankruptcy. The lawns, dogs, and children here seem ever in competition for a "best-groomed" award. Despite their efforts to keep up with one another, the proverbial "Joneses" around here are a largely congenial, cooperative lot. The mostly young, highly educated, overwhelmingly Anglo, and putatively very progressive folks whose children are enrolled in the public school here work in concert with the teachers and administrators to instill in our charges not just academic skills, but also a sense of social responsibility.

Many of these earnest young parents may well be stuck, as Baldwin wrote of the stereotypical white liberal in the 1960s, between publicly disowning a shameful history and privately being "proud of that history for which he does not wish to pay, and from which, materially, he has profited so much." Still others are "dimly, or vividly, aware that the history they have fed themselves is mainly a lie, but they do not know how to release themselves from it, and they suffer enormously from the resulting personal incoherence." These and other fully human complexities-not the least of which is the ever-yawning resource disparity between this school district and the neighboring Detroit schools-are certainly in evidence in this community, these parents, and their children and are certainly worth exploring. But the point here is that this is a marvelous school, the apex of what free public schooling should offer all children in all communities. It is centrally located and its district is carefully laid out so that the vast majority of the kids can walk to school. Each morning they traipse there in groups or in pairs, the older grades on bicycles, the youngest ones astride hand in hand with a parent. Excepting very severe weather, each morning the community's best hopes and future aspirations assemble together outside in the schoolyard to await the bell and a day of instruction. 
If I've set the scene sufficiently, you'll be unsurprised to hear that the schoolchildren's own mock-election from the previous week mirrored that of the popular vote-Hillary Clinton defeated Donald Trump by a sizable margin. Nor should it be surprising to hear that this school's teachers and administration-not to mention many an outspoken parent-were rallying behind the momentum of another potentially historic "first" for the presidency: "the first female president! ... Listen to that, friends, anyone can become president." It goes almost without saying too that the run-up to the election was peppered with a number of lessons about democracy, inclusion, and the great American experiment in meritocracy. Suffice it to say, finally, that this was a school and a parent base rather spectacularly unprepared with the right words to explain to their charges what had transpired in the presidential election of 2016.

The schoolyard gathering the morning after Election Day was saturated with an almost sinister silence, as if the late autumn leaves didn't dare rustle under its weight. Dumbstruck and defeated, many parents just stared in silence, lost for words this morning because the words they'd been using to explain politics to elementary schoolchildren now rang false. The rhetoric of inclusion and equality of opportunity had been dashed by the improbable ascent of a jingoistic misogynist. Daily lessons about respect, sharing, and working together were hardly in step with the now demonstrable success of a conspicuously greedy bully who loudly proclaims to have done it all by and for himself. Still others had eyes burnt scarlet from obvious crying, even a child could see that. Platitudes uttered halfheartedly did nothing to quell the anxious children, many of them seeing in the tears and hearing in the silences-perhaps for the first time in their lives-one of those rare moments when the story changes too abruptly for the words to catch up. I'd like to recall here the profound and reassuring words I shared with my children that morning, but in truth I was mostly silent too. The stunned silence rang out again through the schoolyard on Inauguration Day. Hopes in the Electoral College, or perhaps a constitutional challenge about conflicts of interest, ran foolishly high here. So the morning when we first began the switch from "president elect" to "president" was, to put it mildly, a rather quiet affair. Many of the parents assembled that cold January day had some better words prepared for their children; most hadn't any, just yet, ready for each other.

In his 1965 essay for Ebony magazine, “The White Man's Guilt,” Baldwin reminded readers that the present is always haunted by the past: "The great force of history comes from the fact that we carry it within us, are unconsciously controlled by it in many ways, and history is literally present in all that we do."3 Baldwin's oft-repeated insistence on the weight of history amounts to a perpetual call to situate one's actions, ideas, and motivations in medias res, quite literally in the midst of things. The beginning of one story is, actually, the middle of another larger, longer, narrative. To act, think, and love in the world, then, is to constantly be reckoning with a past that doesn't quite cohere to the developing present. "The obligation of anyone who thinks of himself as responsible is to examine society and try to change it and to fight it-at no matter what risk. This is the only hope 
society has. This is the only way societies change."” The easy succor of grand narrative schemata, Baldwin warns, needs to be cast off and replaced with a fuller accounting of our complex humanity. As we use new words to build new worlds, we must do so with a full accounting of our representative strategies.

The third volume of James Baldwin Review proudly features writers who strive to do just that, to require us to inspect again our stories and to push the limits of the ways we tell and show the world about each other and ourselves. Our volume starts off with a pair of essays that focus attention upon key bookmarks in Baldwin's fiction, his first and last novels. Porter Nenon's essay, “Esther Weren't No Harlot': Rape and Marriage in Go Tell It on the Mountain," turns to Baldwin's debut novel to analyze three under-studied minor characters, Deborah, Esther, and Richard, as figures of heterosexual nonconformity who articulate sophisticated and important critiques of rape and marriage in America at the turn of the twentieth century. Jenny James's essay, "Errant Kinship, Traveling Song: James Baldwin's Just Above My Head," considers James Baldwin's last published novel as the culmination of the author's fictional exploration of kinship, reflecting on the ways distance and loss characterize African-American familial relations.

David Jones's piece, "'Something Unspeakable': James Baldwin and the 'Closeted-ness' of American Power," brings Baldwin's fiction into comparative analysis with the writings of Eve K. Sedgwick, highlighting here the interpretive possibilities opened up by intersectional analyses that view race, sexuality, and national identity as coextensive, reciprocal epistemologies. Jay Garcia's essay, "James Baldwin, Lionel Trilling, American Studies, and the Freudian Tragic," also considers Baldwin from a comparative perspective, this time with the American critic Lionel Trilling. Our fifth and sixth essays bring to light for the first time previously unexamined works and relationships within Baldwin's oeuvre. Apart from a one-off mention in David Leeming's biography, Baldwin's long affiliation with his German editor, Fritz Raddatz, has gone entirely unexamined. Gianna Zocco's essay, "Disturbing the Peace of 'Two Not So Very Different' Countries: James Baldwin and Fritz Raddatz," seeks to break that silence and traces the contours of a decades-long association between these two literary figures. Juxtaposing speeches in print with speeches available only through extensive archival recovery, Davis W. Houck's essay, “'Who's the Nigger Now?': Rhetoric and Identity in James Baldwin's Revolution from Within," breaks new ground as the first fully rhetorical analysis of Baldwin's speechmaking. Our essay section concludes with our Graduate Student Essay Award winner, Dennis Knight, whose essay, "Time to Tell," focuses our attention again on Go Tell It on the Mountain, this time with an eye toward exploring Baldwin's dramatization of the schisms between AfricanAmerican churches and sexuality.

$J B R$ 's current "Dispatches" section includes an accounting from Jules B. Farber about the process of writing his recent biographical work on Baldwin, James Baldwin: Escape from America, Exile in Provence (2016). Here too we've included an extended review of Raoul Peck's I Am Not Your Negro (2016) by Robert Corber, a movie quite literally bestride Baldwin's moment and our own. 
This volume's multi-media section takes the form of a photographic tribute, not to Baldwin per se, but to one of his chief photographers and an associate editor of James Baldwin Review, Sedat Pakay. In a moving piece that accompanies a display of Pakay's photographs, David Leeming and Magdalena Zaborowska memorialize the Turkish photographer who died suddenly last fall. The vibrant and dramatic compositions featured in this section have been generously donated by Sedat Pakay's widow, Kathy, and she deserves special recognition here for her support of our burgeoning journal. Through her generosity, we are also very proud to present this year's volume of $J B R$ with a special tribute cover. Having this image on our cover serves to honor the memory and life of Sedat Pakay and present more of his rich photography to the world. What's more, we've chosen this image of Baldwin near Kilyos Beach in Istanbul from 1965 to remind readers that our favorite firebrand had relaxing moments too. Showing Baldwin at ease here is but one more mark in the full measure of his-and our own-complex humanity. D. Quentin Miller's bibliographic survey of 2010-13 measures as well the complexity of critical engagement with James Baldwin, identifying key trends in recent scholarship.

We are delighted to be ending volume 3 with an interview, "He Gave Me the Words': An Interview with Raoul Peck," by Leah Mirakhor. Mr. Peck's words and views as printed here are his own; they do not represent those of the editors or institutions behind JBR. Ranging from his early reckoning with Baldwin's works, through his previous films and his relationship with the Baldwin estate, on to the reception of his Oscar-nominated film, I Am Not Your Negro (2016), this interview represents the earnest efforts of an artist struggling with his work, its history, and its impact. How Baldwin scholars will reckon with Peck's film-along with his provocative comments here-will, hopefully, play itself out in future volumes of $J B R$.

To err is human, so the proverb goes, and yet failures in leadership are consistently met with astonishment. In part because we all understand and accept that the people in charge of things are, at bottom, people too; they've dreams and desires, hang-ups and vices, and there are things they've done well and things they've royally mucked up. Howsoever history and habitus have informed our decisions and focused our actions, we get on together-if we get on at all-by having faith in our shared humanity. When that faith is tested most, when our highest offices demonstrate daily the full fallibility of authority run amok, we sometimes turn to our artists. We seek from these artists an awful lot: solace, solidarity, and inspiration, surely. Sadness and smiles are needed too, and our artists have always been ready to share their abundant store. In those times when our faith in each other is most strained, there is an urge to seek first conservative council, an assurance of the status quo. James Baldwin, however, refuses such succor. Arguing instead for a search for the hardest truths, the deepest confessions, a systemic upheaval, Baldwin's clarion call rings loudest in those silent moments when our words fail us.

In an earlier turbulent historical and political moment in the life of the U.S., James Baldwin spoke to an assembly of educators-schoolteachers as a matter of 
fact—and his opening comments from 1963 are strikingly poignant to our own moment:

Let's begin by saying that we are living through a very dangerous time. Everyone in this room is in one way or another aware of that. We are in a revolutionary situation, no matter how unpopular that word has become in this country. The society in which we live is desperately menaced, not by Khrushchev, but from within. So any citizen of this country who figures himself as responsible-and particularly those of you who deal with the minds and hearts of young people-must be prepared to "go for broke." Or to put it another way, you must understand that in the attempt to correct so many generations of bad faith and cruelty, when it is operating not only in the classroom but in society, you will meet the most fantastic, the most brutal, and the most determined resistance. There is no point in pretending that this won't happen. ${ }^{5}$

It takes very little imagination to make the leap from Baldwin's words in 1963 to our own moment; substitute Putin—or maybe Pyongyang-for Khrushchev and the coherence is uncanny. Fantastic and determined resistance is surely at the door already. Salivating with Pavlovian anticipation at each public demonstration, adding years to minimum sentencing guidelines, gerrymandering legislative districts without voter input or oversight, siphoning money from public education into private equity and charter school coffers, adding mass to the truncheon blows and velocity to the gunshots of an increasingly militarized police force, rattling sabers in a grand brinksmanship bluster that carelessly puts hundreds of thousands of lives in palpable danger of instant evaporation in a nuclear blast, brutality lurks close behind. It is at our own peril indeed that we pretend all this is not happening.

As word spreads about James Baldwin's visionary insights, and as more and more critics, scholars, and enthusiasts begin to appreciate his insights and rhetorical strategies, we hear more and more about how Baldwin somehow "got it right," or has basically "said all this already." He has been discovered anew as a prophetic voice, and his ominous warnings are parroted with renewed vigor across a wide media landscape. As more people read and use Baldwin to forecast peril, he functions like a modern-day Cassandra, that cursed daughter of Priam from Greek mythology who could accurately forecast the future but would never be believed. ${ }^{6}$

In our own troubled historical moment, it is tempting indeed to look back at the unheeded warnings Baldwin put forth with such force and sophistication, perhaps for inspiration. When we lack the words ourselves, we borrow his. Adopting and adapting his moving words lends the weight of history to the struggles of our moment, precisely because we are stuck together in the middle of the ever-changing story of America. But it is at our own peril here, too, that we forget how in the original mythology Cassandra was murdered-after she was driven insane. That, remember, was the sting of Cassandra's curse. She would be able to predict the future, but no one would believe her. She was driven insane by this 
incongruity. The lessons to be drawn from her plight are numerous, but in closing let us pause over just this one.

It is not enough to forecast or prophesy the future if you cannot convince others to act. Actions, like everything else, flow from words. And if you cannot convince your opponent to even engage in civil dialogue, surely your impasse will last till the end of days. If we are now to "go for broke," to renew our narratives and our collective commitments, we must do so wholly and at the deepest systemic levels. Like our actions, our words matter in the worlds we make. Surely by sword a nation, city, or individual can be conquered and moved to submission in a hush; but hearts and minds are won and moved only when our silences are broken.

\section{Notes}

1 James Baldwin, “The White Man's Guilt" (1965), in Collected Essays, ed. Toni Morrison (New York, Library of America, 1998), p. 724.

2 Ibid., p. 723.

3 Ibid., pp. 722-3.

4 James Baldwin, “A Talk to Teachers" (1963), in Morrison (ed.), Collected Essays, p. 679.

5 Ibid., p. 678.

6 I am indebted to Brian Norman, who first made me aware of the parallels between James Baldwin and the mythological Cassandra. His insightful conference paper from the Baldwin conference in June of 2014 in Montpellier, France, "Posthumous Baldwin and the Cassandra Effect," will hopefully find its way to print soon.

\section{Works Cited}

Baldwin, James, “A Talk to Teachers" (1963), in Collected Essays, ed. Toni Morrison (New York, Library of America, 1998), pp. 678-86.

“The White Man's Guilt” (1965), in Collected Essays, ed. Toni Morrison (New York, Library of America, 1998), pp. 722-7.

Norman, Brian, "Posthumous Baldwin and the Cassandra Effect," conference paper, "James Baldwin: Transatlantic Commuter," Montpellier, France, June 2014.

\section{Contributor's Biography}

Justin A. Joyce is the Managing Editor of James Baldwin Review and research associate to Provost McBride at Emory University. He holds a Ph.D. in English from the University of Illinois at Chicago, where he was thrice an N.C.A.A. Academic All-American as a member of the men's gymnastics team. His work on the American Western genre, gun violence, and self-defense is the subject of his first monograph, Gunslinging Justice: The American Culture of Gun Violence in Westerns and the Law, currently under contract with Manchester University Press. Co-editor of two posthumous publications, Racial Blackness and the Discontinuity of Western Modernity by Lindon Barrett (University of Illinois Press, 2014) and the Lambda Literary Award winning study The Delectable Negro: Human Consumption and Homoeroticism in U.S. Slave Culture by Vincent Woodard (NYU Press, 2014), his work in African-American literature and theory has also appeared in The Oxford 
Guide to the African American Slave Narrative (Oxford University Press, 2014), and A Historical Guide to James Baldwin (Oxford University Press, 2009). Co-editor of A Melvin Dixon Critical Reader (University Press of Mississippi, 2006), he is editing two collections of critical essays, Critical Terms for African American Studies (SUNY Press) and Whose Beloved Community: Black Civil and LGBT Rights (University of Illinois Press). 